\title{
Fiqih Perserikatan Wanita Dalam Politik Dan Jihad
}

\author{
Riza Umami \\ Tadris IPA, Tarbiyah, IAIN Kudus, Indonesia \\ E-mail : risdaanintya@gmail.com \\ Ashif Az Zafi \\ Institut Agama Islam Negeri Kudus, Indonesia \\ E-mail: ashifazzafi@iainkudus.ac.id
}

\begin{abstract}
This scientific article aims to provide understanding and knowledge to readers about the jurisprudence of women's unions in political matters and also women's unions in wars and jihad such as what is good and what Allah accepts. Because many people think that the woman is only a housewife whose job is to educate children and serve their husbands. That women are also allowed to participate in politics and jihad. And there are laws in jihad. The method used for the research of this scientific article uses a qualitative descriptive method that is the data that has been obtained by the author presented in the discussion. In obtaining data the author uses literature in the form of books and journals, and also international journals.
\end{abstract}

Keywords: Woman; Political; Jihad.

\begin{abstract}
Abstrak
Artikel ilmiah ini bertujuan untuk memberi pengetahuan kepada pembaca tentang fiqih perserikatan wanita dalam hal politik, peperangan dan jihad yang baik serta diridhai Allah. Sebab dalam perspektif masyarakat kebanyakan, menilai wanita itu hanya bertugas mengurus rumah tangga. Namun, dilain pihak adapula yang menilai bahwa wanita juga diperbolehkan ikut berpartisipasi baik dalam politik maupun jihad. Penelitian ini merupakan penelitian studi kepustakaan dengan menggunakan metode deskriptif kualitatif yakni data yang telah diperoleh penulis, dipaparkan dalam pembahasan. Dalam memperoleh data, penulis melakukan penelusuran pustaka berupa buku, jurnal baik jurnal nasional maupun jurnal internasional, serta laporan-laporan penelitian. Hasil penelitian menunjukkan bahwa wanita dalam hal politik dan jihad diperbolehkan dengan ketentuannya masing-masing.
\end{abstract}

Kata Kunci: Wanita; Politik; Jihad.

\section{A. Latar Belakang Masalah}

Dalam kehidupan masyarakat muslim pada umumnya dan Indonesia khususnya salah satu konteks yang selalu menjadi perdebatan dalam isu politik adalah terkait kepemimpinan perempuan. Isu ini tidak pernah ada habisnya, 
bahkan akan menjadi "bola liar" tatkala menjelang dan selama berlangsungnya pesta demokrasi baik yang sifatnya lokal maupun nasional. Dengan berkiblat pada paham koservatif serta merujuk pada pendapat Imam Al Ghazali maka terdapat kelompok-kelompok tertentu yang tidak mengakui hak politik perempuan untuk menjadi pemimpin, mereka berkeyakinan bahwa bagi seorang perempuan tidak bisa didudukkan sebagai imam (kepala negara). Hal ini didasari atas pemahaman yang terkandung dalam surah An-Nisa' Ayat 34 bahwa " kaum laki-laki itu adalah pemimpin bagi kaum wanita”. Selain itu, terdapat pula hadis Nabi Muhammad saw yang telah memperingatkan ummatnya bahwa "tidak akan berungtung suatu kaum yang menyerahkan urusannya kepada perempuan “ (H.R. Bukhari). ${ }^{1}$

Selain perdebatan mengenai hak politik perempuan dalam kepemimpinan yang akan selalu hangat untuk diperbincangkan, terdapat pula peran tidak lazim yang mulai dilakoni oleh perempuan dan menimbulkan kekhawatiran mendalam. Sebab, masyarakat Indonesia pernah dikagetkan oleh pristiwa bom bunuh diri secara beruntung yang dilakukan oleh jaringan kelompok radikal-terorisme ditiga tempat (gereja) di Surabaya pada tahun 2018 dan di Mapolsek Surabaya di tahun 2019.

Dalam aksinya, kelompok radikal terorisme tidak lagi terfokus pada lakilaki sebagai aktor utama pelaku bom bunuh diri, namun aktornya mulai bergeser dan melibatkan perempuan serta anak-anak sebagai pelaku bom bunuh diri. ${ }^{2}$ Tentu, banyak faktor yang dapat mempengaruhi keterlibatan perempuan dalam berbagai bentuk teror, akan tetapi satu hal yang perlu digaris bawahi bahwa keberhasilan kelompok radikal-terorisme dalam melibatkan perempuan sebagai pelaku aksi bom bunuh diri tidak terlepas dari keberhasilan dalam melakukan indoktrinisasi paham radikal terorisme, salah satunya mengenai konsep hidup mulia/mati sahid dengan jalan jihad.

\footnotetext{
${ }^{1}$ Abu 'Abdillah Muhammad bin Ismail al- Bukhari, 1994, Shahih Bukhari, Juz V, Dar al-Fikr, Beirut. hal. 32.

${ }^{2}$ Irfan Amir 2020. An Analysis of Jokowi's Policy in Refusing The Return of Formes ISIS Foreign Terrorist Fighters Indonesian Citizens, Jurnal Al-Bayyinah, Vol. 4 No. 1 Tahun 2020, hal 128.
} 
Umumnya, kalangan muslim memahami jihad sebagai bentuk perjuangan maupun peperangan yang dilakukan dalam membela Islam. Sehingga kemudian, tidak sedikit umat muslim yang hanya memaknai jihad sebagai perang melawan musuh Islam. Sempitnya pemaknaan jihad ini terjadi karena salah pemikiran tentang jihad yang ada di dalam kitab-kitab fiqih yang berisi pembahasan tentang perang dan hukum-hukum jihad. Fiqih berarti paham. Sedangkan dalam Bahasa Arab berarti pemahaman dalam suatu hal. Menurut para ulama secara istilah fiqih merupakan ilmu yang mendalami hukum dalam Islam yang bersumber pada Alqur'an, sunnah \& ijma'. 3

Sebagaimana penulis telah uraikan diatas, maka batasan rumusan masalah yang akan dibahas dalam artikel ilmiah ini hanya terbatas pada bagaimana fiqih perserikatan perempuan (wanita) dalam politik, peperangan dan jihad. Hal ini penting, mengingat perkembangan sistem pemerintahan negara modern saat ini seperti Indonesia yang penduduknya mayoritas muslim, menganut paham demokrasi konstitusional. Dengan salah satu cirinya adalah pemilihan kepala negara maupun kepala daerah diserahkan sepenuhnya kepada rakyat melalui sistem pemilihan umum secara langsung, tanpa memandang laki-laki maupun perempuan sebagai calon.

\section{B. Metode Penelitian}

Penelitian ini merupakan penelitian studi kepustakaan dengan menggunakan metode deskriptif kualitatif, yakni data yang telah diperoleh penulis, kemudian dianalisa, dijabarkan serta dipaparkan secara sistematis dalam pembahasan. Untuk memperoleh data, penulis melakukan penelusuran bahan pustaka yang terdiri dari buku, kitab dan jurnal ilmiah baik jurnal nasional maupun jurnal internasional.

\section{Pembahasan}

\section{Fiqih Perserikatan Wanita Dalam Politik}

Menurut Jalalul Mahali, fiqih merupakan ilmu yang menjelaskan hukum secara syara' yang memiliki hubungan amaliyah yang diusahakan dengan

\footnotetext{
${ }^{3}$ Al-Qur'an wajib menjadi dalil syar'I yang pertama - Lajnah an Nadwah al-Ilmiyyah (LNI) PP.Al-Anwar.
} 
memperolehnya dari sumber dalil yang jelas. Sedangkan fiqih menurut bahasa yang berarti "paham", dalam surat An-Nisa' (78) :

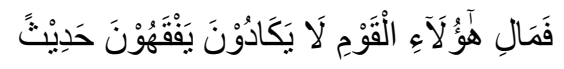

Artinya:

"Maka mengapa orang-orang itu (orang munafik) hampir-hampir tidak memahami pembicaraan sedikitpun?".

Dan sabda Rasulullah saw. "Sesungguhnya panjangnya shalat dan pendeknya khutbah seseorang, merupakan tanda akan kepahamannya."4

Fiqih dalam istilah mempunyai makna yakni hukum syariat yang terkait dengan perilaku dan pengucapan mereka yang sudah terbebani menjalankan syariat agama, yang diambil dari sumber dalil-dalil yang bersifat terperinci, yang berupa al-Quran dan sunnah dan yang bercabang darinya yakni ijma' dan ijtihad.

Menurut Ibnu Khaldun bahwa dalam kehidupan masyarakat peranan politik sangat penting. Dalam mencapai keselamatan dunia dan akhirat manusia menggunakan mekanisme politik. Dengan politik manusia berusaha agar dapat bekerjasama untuk memenuhi keperluan pokok dan untuk mempertahankan diri. Di samping itu, politik juga menjaga manusia agar tidak tenggelam dalam nafsu yang destruktif. ${ }^{5}$ Dalam firman Allah al-Quran Surat At Taubah (71) yang berbunyi:

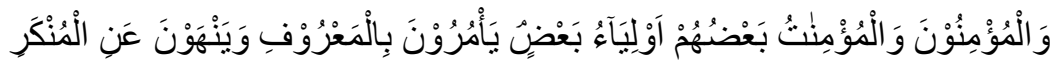

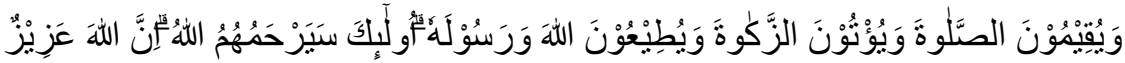

Artinya :

"Dan orang-orang yang beriman, laki-laki dan perempuan, sebagian mereka (adalah) menjadi penolong bagi sebagian yang lain. Mereka menyuruh (mengerjakan) yang ma'ruf mencegah dari yang mungkar, mendirikan shalat, menunaikan zakat, dan mereka taat kepada Allah dan

\footnotetext{
${ }^{4}$ Muslim No.1437, Ahmad No.17598, Daarimi No.1511.

5 Asma Barlas, 2005, Cara Qur'an Membebaskan Perempuan, Alih Bahasa R. Cecep Lukman Yasin, Serambi Ilmu Semesta, Jakarta,hal.68-69.
} 
Rasul-Nya. Mereka itu akan diberi rahmat oleh Allah. Sesungguhnya Allah Mahaperkasa lagi Mahabijaksana.“

Pada ayat tersebut Allah menjelaskan bahwa semua komunitas diberikan amanah mulai dari kalangan mukmin dan mukminah yang memberikan penerangan. Allah juga memberikan keduanya tanggung jawab atasnya, tidak dimaafkan dari kalangan mukmin dan begitu pun kalangan mukminah, terlebih Allah taala berfirman dalam al-Quran Surah At Taubah Ayat 71

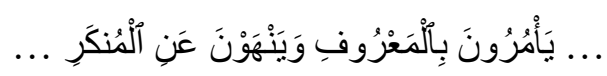

Setiap jiwa memiliki tanggung jawab menyeluruh, baik laki-laki maupun perempuan dalam sebuah elemen komunitas politik, perkantoran, perekonomian, pemikiran dan perkumpulan untuk menyuruh (mengerjakan) yang ma'ruf dan mencegah dari yang mungkar. Lebih lanjut untuk menguatkan pemahaman pada ayat 71 surat At-Taubah, sabda Nabi saw yang artinya: "Barang siapa yang tidak memperhatikan permasalahan kaum muslimin maka ia bukan termasuk kalangan mereka. (HR Baihaqi dalam Kitab Syi'bul Iman).

Ayat 71 surat At Taubah juga menjelaskan perempuan sama halnya seperti laki-laki. Mereka boleh berpartisipasi dalam politik dan mengatur urusan masyarakat, dan juga mempunyai hak dalam mengatur kepentingan umum. Hal ini penting untuk dipahami sebab didalam masyarakat muslim masih terdapat kelompok-kelompok tertentu yang menegasikan partisipasi perempuan dalam hal politik, khususnya kepemimpinan perempuan dalam ranak domestik maupun publik. Setidaknya menurut Musdah Mulia dan Anik Farida, terdapat tiga alasan yang menjadi dasar keyakinan kelompok yang mengklaim bahwa Islam tidak mengakui hak perempuan menjadi pemimpin, baik dalam ranah domestic maupun dalam ranah public. Pertama, argumentasi dari al-Quran yaitu ayat al-Rijal Qawwamuna A'la al-Nisan (laki-laki adalah pemimpin bagi kaum wanita ), kedua, argumentasi berupa qiyas (analogi). Sebagian ulama menyatakan tidak boleh perempuan menjadi pemimpin, mengambil tidak bolehnya perempuan menjadi imam shalat atau tidak bolehnya perempuan pergi sendirian tanpa ditemani muhrimnya. Dan ketiga, argumentasi berupa ijma (konsensus). Ijma itu 
diambil berdasarkan pengalaman empiris di dunia Islam, yaitu sejak masa Rasul dan khulafaur rasyidin serta generasi sesudahnya, tidak pernah perempuan mendapat tempat dalam kepemimpinan umat. ${ }^{6}$

Sehubungan dengan alasan yang disebutkan diatas, menurut M. Quraish Shihab, ${ }^{7}$ pendapat yang terkesan diskriminasi terhadap perempuan (menegasikan hak-hak politik perempuan) tidak sejalan dengan ayat serta makna yang sebenarnya yang diamanatkan dalam surah An-Nisa ayat 34 yang artinya "kaum laki-laki itu adalah pemimpin bagi kaum wanita..",

Menurutnya ayat 34 surah An-Nisa berbicara tentang kepemimpinan lakilaki (suami) terhadap keluargannya, dalam bidang kehidupan rumah tangga. Lebih lanjut menurutnya kepemimpinan dalam Islam tidak mencabut hak-hak isteri dalam berbagi segi. ${ }^{9}$ Oleh sebab itu dalam islam, kedudukan perempuan diangkat dan dimuliakan sehingga hak-hak politik perempuan dapat pula kita persamakan dengan laki-laki, yang meliputi (i) Hak berpendapat dalam pemilihan dan referendum dengan berbagai cara. (ii) Hak mencalonkan diri menjadi anggota lembaga perwakilan dan anggota setempat, (iii) Hak dalam mencalonkan diri menjadi presiden dan hal-hal lain yang mengandung kerjasama dan menyampaikan pendapat yang berkaitan dengan politik. ${ }^{10}$ Hak-hak tersebut akan dijelaskan sebagai berikut:

\section{a) Kebebasan untuk menyampaikan pendapat.}

Saling bertukar pikiran merupakan sebuah prinsip yang sangat penting dalam Islam. Untuk menciptakan sebuah bangsa yang berhasil, Islam mengajak setiap pengikutnya untuk sama-sama menasehati dan bermusyawarah satu sama lain. Yang dijelaskan pada surat Asy- syura

\footnotetext{
${ }^{6}$ Siti Musdah Mulia dan Anik Farida, 2005, Perempuan dan Politik, PT Gramedia Pustaka Utama, Jakarta. hal. 60-61

${ }^{7}$ M. Quraish Shihab, Perempuan; dari Cinta sampai Seks dari Nikah Mut'ah sampai Nikah Sunnah dari Bias Lama sampai Bias Baru, hal. 274

${ }^{8}$ Departemen Agama RI, Alquran dan Terjemahannya, hal.123.

${ }^{9}$ Departemen Agama RI, Alquran dan Terjemahannya, hal. 123.

${ }^{10}$ Mohammad Mais Qosim Ja'far, Perempuan dan Kekuasaan, Terjemah Ikhwan Fauzi, hal. 36 .
} 
(38). "dan (bagi) orang-orang yang menerima (mematuhi) seruan Tuhan dan melaksanakan salat, sedang urusan mereka (diputuskan) dengan musyawarah antara mereka; dan mereka menginfakkan sebagian dari rezeki yang Kami berikan kepada mereka,"11 Ayat tersebut menjelaskan bahwa pentingnya bermusyawarah dalam menyelesaikan sebuah persoalan. Karena semua laki-laki maupun perempuan dalam menyelesaikan masalah atau urusan agar menggunakan musyawarah dalam mengambil keputusan. Maka baik laki-laki maupun perempuan dapat menyampaikan pendapatnya pada saat musyawarah. Pada saat menyampaikan pendapat, mereka dapat memberikan nasehat yang berharga dan bijaksana untuk kepentingan umat Islam dan juga mengikuti prinsip menyuruh kebaikan dan melarang kejahatan (amar ma'ruf nahi munkar). Islam juga memberikan kebebasan dalam berpendapat asalkan sopan, santun dan tidak menyinggung perasaan orang lain.

\section{b) Hak terhadap pemilihan}

Persoalan politik dalam memperhitungkan dan menghargai dapat memberikan pengaruh besar dalam membentuk masyarakat itu sendiri. ${ }^{12}$ Allah berfirman:"Wahai orang-orang yang beriman! Taatilah Allah dan taatilah Rasul (Muhammad), dan Ulil Amri (pemegang kekuasaan) di antara kamu. Kemudian, jika kamu berbeda pendapat tentang sesuatu, maka kembalikanlah kepada Allah (al-Qur'an) dan Rasul (Sunnahnya), jika kamu beriman kepada Allah dan hari kemudian. Yang demikian itu, lebih utama (bagimu) dan lebih baik akibatnya." (QS. An Nisa':59). ${ }^{13}$

Pada ayat tersebut dijelaskan tentang suatu Negara yang mempercayakan administrasi pemerintahannya kepada seorang pemimpin. Setiap orang muslim mempunyai hak ikut dalam memilih pemimpin, secara langsung maupun tidak langsung. Sedangkan perempuan juga sama berhak dalam menentukan nasibnya sendiri dan nasib bangsanya. Sebab

\footnotetext{
${ }^{11}$ Tohari, et al., op. cit., hal. 487.

${ }^{12}$ Syekh Syaukat Hussein, HAM dan Islam, Terjemah Abdul Rochim, hal.18.

${ }^{13}$ Tohari, et al., op. cit., hal.87.
} 
setiap manusia memiliki hak dalam memilih seorang presiden dan menduduki jabatan di pemerintah. ${ }^{14}$

\section{c) Hak mendapat perlindungan kehormatan}

Dalam firman Allah, Al-Hujurat (11) : "Hai orang-orang yang beriman. Janganlah suatu kaum mengolok-olok suatu kaum yamg lain karena boleh jadi mereka yang diolok-olok lebih baik dari pada mereka...". Ayat tersebut menjelaskan tentang melindungi kehormatan sesama manusia, saling berbuat baik antar sesama dan tolong menolong, terutama kaum perempuan. Sebab Allah memerintahkan kepada kita untuk saling melindungi \& membela kaum perempuan, dan juga membantu integrasi mereka ke masyarakat \& memberikan kehidupan yang terhormat. $^{15}$

\section{d) Kepemimpinan perempuan}

Dalam Islam, manusia berstatus sebagai khalifah bertolak belakang dengan bidang kepemimpinan perempuan. Pada surat Al-Ahzab mempertegas kekhalifahan manusia dimuka bumi ini. Manusia dalam mengemban amanat dari Allah ialah untuk mengolah, memelihara, dan mengembangkan bumi.

Pada surat Al-Ahzab (35): "Sesungguhnya laki-laki dan perempuan yang muslim, laki-laki dan perempuan yang mukmin, laki-laki dan perempuan tetap dalam ketaatanya, laki-laki dan perempuan yang benar, laki-laki dan perempuan dalam keadaan sabar, laki-laki dan perempuan yang khusyu', laki-laki dan perempuan yang bersedekah, laki-laki dan perempuan yang berpuasa, laki-laki dan perempuan yang memelihara kehormatannya, laki-laki dan perempuan yang banyak menyebut (nama) Allah, Allah telah menyediakan untuk mereka ampunan dan pahala yang besar". ${ }^{16}$

\footnotetext{
${ }^{14}$ Fatimah Umar Nasif, Hak dan Kewajiban Perempuan dalam lslam, Terjemah Burhan Wirasubrata, hal. 172.

${ }^{15}$ Ahmad Zaki Yamani, Syariat Islam yang Kekal dan Persoalan Masa Kini, hal.66.

${ }^{16}$ Depag RI, Al-Qur'an dan Terjemah, Jakarta, hal. 673.
} 


\section{e) Kegiatan politik}

Faktor kemaslahatan merupakan masalah paling penting yang bersangkutan dengan kemasyarakatan dan politik. Ibnu Qoyyim alJauziyah, mengutip ucapan Ibnu Aqil yang mengatakan : “Cara-cara yang diperlukan untuk mengantarkan urusan-urusan politik pada masyarakat di kehidupan yang menjamin kemakmuran dan menghindarkan mereka dari kerusakan atau kebinasaan walaupun cara tersebut tidak pernah dicontohkan oleh Rasulullah dan tidak merupakan wahyu Allah. ${ }^{17}$

\section{f) Kepemimpinan perempuan dalam negara}

Firman Allah dalam al- Quran, An-Naml (23-24) yang artinya: "Sesungguhnya aku menjumpai seorang wanita yang memerintah mereka, dan Dia dianugerahi segala sesuatu serta mempunyai singgasana yang besar. Aku (burung hud-hud) mendapati Dia dan kaumnya menyembah matahari, selain Allah; dan syaitan telah menjadikan mereka memandang indah perbuatan-perbuatan (buruk) mereka lalu menghalangi mereka dari jalan (Allah), sehingga mereka tidak dapat petunjuk."

Pada ayat tersebut dijelaskan bahwa al-Quran memuji kepemimpinan dan kebijaksanaan Ratu Bilqis dalam memerintah kerajaan Saba'iyah. Yang prinsipnya bagi siapa saja yang mampu maka ialah yang wajar umtuk menjadi pemimpin. Akan tetapi kepemimpinan Ratu Bilqis tidak baik, sebab segala perbuatan baik yang dilakukan, tertutupi dengan keimanannya yang menyembah kepada matahari. Ayat tersebut pula menjelaskan kegagalan Ratu Bilqis dalam ketauhidan. Kaum Ratu Bilqis pun tidak beriman kepada Allah melainkan sama dengannya menyembah matahari. $^{18}$

17 Faizal, Liky. Januari-Juni 2016. "Perempuan Dalam Politik (Kepemimpinan Perempuan Perspektif Al-Qur'an)". Jurnal TAPIs. Vol.12, No.1. http://ejournal.radenintan.ac.id/index.php/TA PIs/article/viewFile/830/713 18 Maret 2020. hal. 107.

18 Faizal, Liky. Januari-Juni 2016. "Perempuan Dalam Politik (Kepemimpinan Perempuan Perspektif Al-Qur'an)”. Jurnal TAPIs. Vol.12, No.1. http://ejournal.radenintan.ac.id/index.php/TA PIs/article/viewFile/830/713 18 Maret 2020. hal.107 
Dari hak wanita dan kewajiban dalam memerintahkan pada kebaikan dan mencegah kemungkaran, dan juga memperhatikan urusan muslimah. Pada hakikatnya mempunyai hak pilih suara dalam pemilihan delegasi dan menteri-menteri terlebih bahwa pemilihan merupakan pekerjaan pendelegasian. Seseorang berangkat menuju tempat pemungutan suara, lalu memberikan hak pilihnya sesuai dengan pilihannya untuk orang yang mempermisalkan, seperti wakil dalam suatu parlemen menuntut hakhaknya dan mempertahankan pendapat atau memilih dengan pendapatannya pada orang yang memilihnya menjadi pemimpin negara (Presiden). Tidak ada dalam Islam sesuatu yang mencegah wanita untuk mewakilkan kepada orang yang dia pandang sebagai orang yang baik dan mencukupi untuk menyatakan pendapatnya dan untuk menuntut hakhaknya. ${ }^{19}$

Dalam artian bahwa perempuan juga memiliki hak dan kewajiban dalam berpolitik atau berparlemen. Perempuan juga bisa menjadi anggota pemerintahan, anggota partai, atau anggota dalam bidang politik. Biarpun perangkat hukum sudah mau menerima kewenangan, keputusan yang diambil pemimpin dalam partisipasi politik seorang perempuan. Hingga sekarang politik dan perempuan adalah dua hal yang sulit dikaitkan. ${ }^{20}$

Seperti layaknya seorang wanita yang berkompeten dalam mengkritik dan mengontrol karena yang dipaham dari pengkritikan dan pengontrolan mengandung penjelasan beberapa segi yang benar dan yang salah. Hal tersebut pula berisi peringatan terhadap beberapa kekurangan atau dengan pernyataan secara Islam: mengandung perintah pada kebaikan dan mencegah dari kemungkaran.

Islam telah menjadikan hal ini merupakan hak bagi wanita, bahkan suatu kewajiban baginya, sebagaimana kalam Allah Taala:

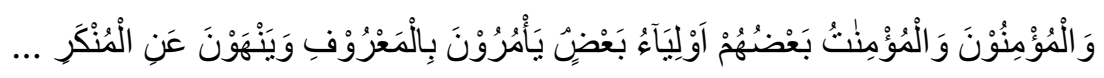

${ }^{19}$ El Khosht Mohamed Osman, op. cit., hal. 297.

${ }^{20}$ Romany Sihite, 2007, Perempuan Kesetaraan Keadilan Tinjauan Berwawasan Gender, PT. Raja Grafindo Persada, Jakarta, hal.158. 


\section{Artinya:}

Dan orang-orang yang beriman, laki-laki dan perempuan, sebagian mereka menjadi penolong bagi sebagian yang lain. Mereka menyuruh (berbuat) yang ma'ruf, dan mencegah dari yang mungkar... (At-Taubah:71). ${ }^{21}$

Sebagaimana bahwa hak pengkritikan dan pengontrolan masuk dalam lingkup (perhatian dengan urusan muslimin) yang Rasulullah saw menjadikannya sebagai simbol persatuan jamaah muslimin tatkala bersabda dalam hadis "Barang siapa yang tidak memperhatikan urusan muslimin maka dia tidak termasuk golongan mereka." Terlebih yang berkaitan dengan wanita saja. Ketauhilah bahwa wanita lebih menguasai urusan-urusan mereka daripada laki-laki. ${ }^{22}$

Inilah suatu hal yang dibenarkan juga bahwa wanita mengurusi wilayahwilayah khusus, seperti kantor-kantor, sekolah-sekolah, rumah sakit-rumah sakit, yayasan-yayasan sosial, bahkan perekonomian. Riwayat dari Umar bin AlKhaththab yang diriwayatkan oleh Ibnu Hazm bahwasannya dia mewakilkan kepada Asy syifa' (wanita dari kalangan kaumnya) urusan pasar. ${ }^{23}$

Hadits yang menyatakan larangan mengurus suatu wilayah yang berkaitan dengan wilayah besar, yaitu urusan kekhilafahan, Rasulullah saw. bersabda, “ Tidak akan ada keberuntungan suatu kaum yang menyerahkan urusan kepada wanita." (HR Bukhari, Turmudzi, Nasa'i, dan Ahmad). Hal ini khusus dengan wilayah secara umum, maksudnya kepemimpinan Negara, bukan wilayah-wilayah khusus. Sebab, Rasulullah saw telah menyatakan sabda ini ketika mendengar orang Persia mengangkat Puteri Kisra sebagai raja. Adapun dalam suatu riwayat dari Hakim dan Ibnu Hibban, beliau mengatakannya ketika sampai berita kepadanya bahwa raja Dzu Yazan meninggal dunia, lalu mereka menyerahkan urusan kepada wanita (istri). ${ }^{24} \mathrm{Hal}$ ini menunjukkan bahwa larangan darinya

${ }^{21}$ Tohari, et al., op. cit., hal. 198.

${ }^{22}$ El Khosht Mohamed Osman, op. cit., hal. 297.

${ }^{23}$ Rasjid H Sulaiman, 2007, Fiqih Islam, Al-Muhalla jld.9, Sinar Baru Algensindo, Bandung, , hal. 429-430.

24 Al-Maqasidul Hasanah lis-Sakhowi, Bidarisati wa Tahqiqi, Hadits No.878, Darul Kutubil 'Arabi-Beirut, hal. 540-541. 
hanya pada kekhilafahan yang besar (Sebagian kitab menyatakan bahwa wanita tidak ahli dari segi akal dan pengalaman sosial).

\section{Perserikatan Wanita Dalam Peperangan dan Jihad}

Jihad yang berarti memerangi kepada kaum kafir yang dianggap musuh, yang bertujuan untuk membela agama Allah. Tujuan jihad yakni untuk memelihara, membela dan menjunjung tinggi agama Allah. ${ }^{25}$ Meskipun demikian para ulama berpendapat bahwa hukum jihad yaitu fardhu 'ain bagi setiap orang Islam, akan tetapi hukum perang yang lebih baik yakni fardhu kifayah yang berarti wajib bagi beberapa umat Islam. Apabila sebagian umat muslim sudah melaksanakannya dan sudah dianggap cukup pada saat itu bilangannya, maka tidak wajib orang lain yang belum mengerjakannya, kecuali pada situasi darurat atau memaksa, saat itu hukum berubah menjadi fardhu 'ain. ${ }^{26}$ Pada firman Allah surat An-Nisa (95):

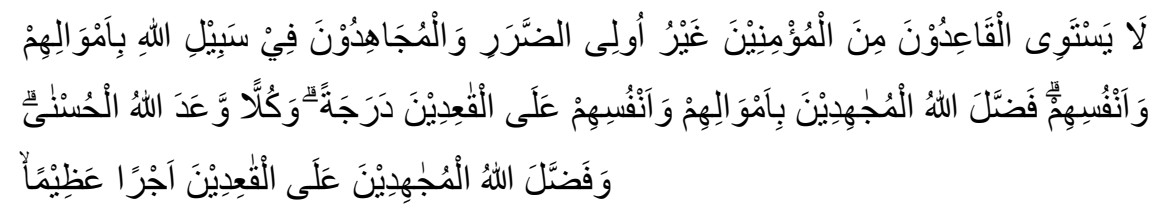

Artinya :

"Tidaklah sama antara orang beriman yang duduk (yang tidak turut berperang) tanpa mempunyai unzur (halangan) dengan orang yang berjihad dijalan Allah dengan harta dan jiwanya. Allah melebihkan derajat orang-orang yang berjihad dengan harta dan jiwanya atas orang-orang yang duduk (tidak ikut berperang) tanpa halangan. Pada masing-masing Allah menjanjikan (pahala) yang baik (surga) dan Allah melebihkan orang-orang yang berjihad atas orang yang duduk dengan pahala yang besar, “. ${ }^{27}$

Jihad merupakan salah satu amal yang paling utama suatu ketika, Abdullah bin Mas'ud bertanya kepada Nabi saw, "Amal apakah yang paling utama?" Nabi saw menjawab, "Shalat pada waktunya." Kemudian Abdullah bertanya lagi, "Kemudian apa lagi?" Nabi saw menjawab, "Berbakti kepada kedua orang tua." Lalu Abdullah bertanya lagi, "Kemudian apa lagi?" Nabi saw menjawab , "Jihad dijalan Allah."

\footnotetext{
${ }^{25}$ Rasjid H Sulaiman, op. cit., hal. 447.

${ }^{26}$ Rasjid H Sulaiman, op. cit., hal. 452-453.

${ }^{27}$ Tohari, et al., op. cit., hal.94.
} 
Abdullah berhenti menanyakan lagi kepada Rasulullah, dia kemudian berkata, "Seandainya aku menambah terus pertanyaan, beliau pasti akan menambah jawabannya kepadaku." (HR Al Bukhari, 2574).

Ada juga yang berpendapat bahwa jihad hukumnya fardu kifayah yang tidak wajib atas orang-orang yang beruzur dengan sebab uzur-uzur mereka. Pada hadits yang diriwayatkan oleh HR Bukhari, Turmudzi, Nasa'i, dan Ahmad. "Tidak akan ada keberuntungan suatu kaum yang menyerahkan urusan kepada wanita." Meskipun demikian, akan tetapi tidak wajib pula bagi wanita atas kesibukan urusan rumah tangga dan anak-anaknya. Meskipun demikian wanita dibolehkan berserikat dalam jihad dengan izin suaminya. ${ }^{28}$

Hukum tersebut mulai berlaku apabila musuh belum menyerang, namun ketika musuh belum memberikan serangan. Maka hukum jihad menjadi wajib bagi setiap individu dan juga wajib bagi mereka membalas serangan musuh tanpa harus meminta izin dulu kepada suaminya.

Adapun sebagai contoh dalil-dalil dan berita-berita yang terjadi pada masa Rasulullah saw yaitu tentang suatu rombongan wanita muslimah yang bangkit dalam perserikatan, pembelaan, dan peperangan. Seorang wanita berkata kepada Rasulullah saw, "Wahai Rasulullah, berdoalah kepada Allah supaya menjadikanku dari kalangan mereka (orang yang mengendarai laut hijau di jalan Allah) maka beliau bersabda, "Ya Allah, jadikanlah dia dari kalangan mereka."” (HR. Bukhari).

HR.Bukhari juga meriwayatkan dari Anas, beliau berkata, "Pada hari Perang Uhud beberapa orang yang menyerang Nabi saw, sedangkan aku melihat Aisyah dan Ummu Sulaim. Keduanya sungguh bersegera - aku melihat betis keduanya - keduanya memindahkan qirbah (kantong air terbuat dari kulit) ke atas punggung keduanya, kemudian keduanya menuangkan qirbah-qirbah tersebut pada mulut-mulut kaum muslimin, lalu keduanya kembali pulang." Yang dimaksudkan "aku melihat betis keduanya" adalah gelang kaki keduanya atau lebih tepatnya tempat gelang-gelang kaki darinya. Lalu yang dimaksud "ke atas punggung keduanya" yakni punggung keduanya.

\footnotetext{
${ }^{28}$ Rasjid H Sulaiman, loc. cit.,
} 
HR.Muslim juga meriwayatkan "Bahwasannya beliau berada dalam Perang Hunain, aku melihat Ummu Sulaim membawa golok. Kemudian, Nabi saw bertanya kepadanya, "Untuk apa golok ini?" Dia menjawab, “Aku mengambilnya, apabila ada salah seorang musyrik mendekat kepadaku, pasti aku tusukkan benda ini ke perutnya."

Bagitu juga Ibnu Sa'id yang meriwayatkan dalam kitab Thabaqat-nya, "Bahwasannya Ummu Ammarah binti Ka'ab menyaksikan seseorang bersama suami dan dua anaknya, dia keluar bersama mereka dengan keadaan yang ada dipermulaan siang untuk memberi minum kepada orang-orang yang terluka. Lalu dia mengatakan bahwa pada hari itu telah menimpanya musibah yang baik dan luka dengan dua belas luka tususkan tombak atau sabitan pedang."

Keterlibatan wanita pada urusan-urusan peperangan tidak terbatas pada keikutsertaan. Bahkan Islam memuliakannya dengan sebenar-benar kemuliaan yang tersendiri dalam hal ini. Oleh karena itu, Islam memberikan hak jaminan keamanan dari kedua pihak yang bertikai. Maksudnya bahwa memberikan hak pembelaan diri dari kaum non muslim yang menginginkannya, baik saat perang maupun pada saat damai.

Turmudzi meriwayatkan dan juga mengatakan bahwa hadits ini Hasan Gharib, dari Rasulullah saw bersabda, "Sesungguhnya wanita itu boleh meminta perlindungan pada suatu kaum.” Maksudnya yakni memohon pertolongan kepada kaum muslimin. Abu Dawud Nasa'I meriwayatkan dari Aisyah, beliau berkata "Jika seorang wanita meminta perlindungan kepada kaum mukmin, hal itu boleh." Maksudnya bahwa apa yang ia lakukan (meminta perlindungan kepada orang yang diinginkan) ini, Islam menghormatinya. Tak seorang pun diperkenankan melarangnya. Sebagaimana yang diriwayatkan Abu Dawud, Ahmad, dan Ibnu Majah dari Rasulullah saw, Beliau bersabda, "Kedudukan orang Islam kepada sesamanya itu setara, baik kepada orang yang kuat maupun orang yang lemah.”

Kejadian-kejadian yang terjadi pada masa kenabian yang dikuatkan dengan penguatan perbuatan pada hak wanita dalam persewaan bagi yang menginginkan, sebagaimana dua syaikh meriwayatkan: bahwa Ummu Hani’ binti Abu Thalib - saudara perempuan Ali karramallaahu wajhah - dia menyewa 
seorang laki-laki dari kalangan musrik pada hari Fathu Makkah, lalu Ali bin Abi Thalib enggan dengannya, kecuali hendak membunuhnya, lalu Ummu Hani' bersegera datang kepada Rasulullah saw, lalu dia berkata,'Wahai Rasulullah saw. putra ayahku, yaitu Ali bin Abi Thalib menuduh bahwasannya dia sebagai pembunuh orang yang aku telah melindunginya - dia menyebutkan suatu nama lalu, Rasulullah saw. menjawab, “ Kami telah memberikan perlindungan kepada orang yang telah kamu sewa, wahai Ummu Hani' (Nailul)”.

\section{Penutup}

Berdasarkan penjelasan, uraian dan pemaparan diatas diketahui bahwa Fiqih perserikatan wanita dalam politik, bahwa seorang wanita juga memiliki hak dan kewajiban yang sama halnya seperti laki-laki, tidak menutup kemungkinan wanita juga bisa ikut andil dalam berpolitik. Surah At Taubah ayat 71, menunjukkan bahwa seorang perempuan sama halnya seperti laki-laki. Masingmasing mereka berhak berpartisipasi dalam politik dan mengatur urusan masyarakat, dan juga mempunyai hak yang mengatur kepentingan masyarakat. Dalam artian bahwa perempuan juga memiliki hak dan kewajiban dalam berpolitik atau berparlemen. Perempuan juga bisa menjadi anggota pemerintahan, anggota partai, atau anggota dalam bidang politik. Tidak harus menuntut seorang laki-laki yang menjadi anggota pemerintah, anggota parlemen, dan anggota partai. Selanjutnya yakni perserikatan wanita dalam peperangan dan jihad. Dalam berjihad hukumnya yakni fardhu 'ain bagi setiap orang islam, akan tetapi yang lebih baik hukum peperangan adalah fardu kifayah, yang berarti wajib atas beberapa umat Islam. Yang telah diterangkan di alquran surat An-Nisa: 95, jihad merupakan salah satu amal yang paling utama.

\section{Daftar Pustaka}

\section{Buku-Buku}

Al-Maqasidul Hasanah lis-Sakhowi, bidarisati wa tahqiqi, hadits No.878, Darul Kutubil 'Arabi-Beirut.

Barlas, Asma, 2005, Cara Qur’an Membebaskan Perempuan, Alih Bahasa R.

Cecep Lukman Yasin, Serambi Ilmu Semesta, Jakarta.

Depag RI, Alqur'an dan Terjemah, Jakarta.

Tohari, et al., Al-Quran Madina, Madina, Bandung.

Hussein, Syekh Syaukat, HAM dan Islam, Terj. Abdul Rochim. 
Jaelani, Aan, "Islam, Gender And Fundamentalism-Radicals In A Global Political Economy", Pusat Gender IAIN Syekh Nurjati Cirebon, MPRA Paper No.69527.

Ja'far, Mohammad Mais Qosim, Perempuan Dan Kekuasaan, Terjemah, Ikhwan Fauzi.

Mohamed Osman, El Khosht, 2015, Fiqh Wnita: Dari Klasik sampai Modern, Tinta Medina, Solo.

Nailul Author jid.8 hlm.17, Fathul Qadir jld.4 hlm.278, Ad-Durrul Mukhtar jld.3 hlm.239, Al-Badai' jld.7 hlm.98, Al-Mughni jld.8 hlm.346, Tabyinul Haqaiq jld.3 hlm.247, Al-Islam 'Aqidah wa Syari'ah no.228, Al-Islam wa Qadloyal Mar'atul Mu'ashiroh no.28.

Nasif, Fatimah Umar, Hak Dan Kewajiban Perempuan Dalam Islam, Terj. Burhan Wirasubrata.

Al-Qur'an wajib menjadi dalil syar'i yang pertama - Lajnah an Nadwah alIlmiyyah (LNI) PP.Al-Anwar.

Sihite, Romany, 2007, Perempuan Kesetaraan Keadilan Tinjauan Berwawasan Gender, PT.Grafindo Persada, Jakarta.

Sulaiman, Rasjid H, 2007, Fiqh Islam. Al-Muhalla. jld.9, Sinar Baru Algensindo, Bandung.

Syafiq, Hasyim, Hal-Hal Yang Tak Terpikirkan Tentang Isu-Isu Keperempuanan Dalam Islam.

Yamani, Ahmad Zaki, Syariat Islam Yang Kekal Dan Persoalan Masa Kini.

Jurnal/Artikel Ilmiah

Amir, Irfan. 2020. "An Analysis Of Jokowi'S Policy In Refusing The Return Of

Former ISIS Foreign Terrorist Fighters Indonesia Citizens.” Al-Bayyinah:

Jurnal of Islamic Law 4 (1): 118-32. https://doi.org/10.35673/albayyinah.v3i2.492.

Faizal, Liky, "Perempuan Dalam Politik (Kepemimpinan Perempuan Perspektif Al-Qur'an), Jurnal TAPIs, Vol.12, No.1, Januari-Juni, 2016.

Haryanti, Yanti, "Kontribusi Ajaran Islam Tentang Hak Politik Perempuan", Mazahib Jurnal Pemikiran Hukum Islam, Vol.XV, No.1, Juni, 2016.

Mansur, 2014 "Perspektif Ham Dalam Fiqh Al-Jihad", Jurnal Agama dan Hak Azazi Manusia, Vol.4, No.1, November, 2014. 